\title{
自動運転の実現に向けた 法的課題
}

藤原靜雄

\section{はじめに}

AI (人工知能) と IoT (Internet of things) の進化・展開により自動運転の実現が現実味を 帯び始め、世界的な競争が始まっている。わ が国政府も2014年には、官民ITS（Intelligent Transport Systems：高度道路交通システム) 構想・ロードマップを公にし、これを2019年 まで毎年改定している ば、とくに、2020年までの (1)高速道路での自 動運転、(2)限定地域での無人自動運転移動サー ビスの実現が目指されている。もっとも、一般 道では、まだ運転支援といったレベルの実現が 目標である。その後、2025年頃には、高速道 路での完全自動運転をはじめレベルの高い自動 運転が普及していくという予想である。また、
MaaS（Mobility as a Service）を前提としたま ちづくりを行い、全ての地域・全ての人が新た なモビリティサービスを利用できるという将来 像が展望されている。

以上のような展開を政府は考えているが、忘 れてならないのは、2020年あるいは2025年で も、自動運転は道路交通においてまだ少数派で あり、通常の人が運転する車と混在（混合交通） が見込まれるところ、多数派は人が運転してい る車であるという点である。

\section{議論の前提}

自動運転の可能性、基礎的概念など、自動運 転をめぐる課題を検討する場合の共通の知見を 紹介する必要があるが、紙幅の関係で省略せざ

表1 自動運転のレベル

\begin{tabular}{|c|c|c|}
\hline SAE レベル & 概要 & 監視、対応主体 \\
\hline 0（自動化なし） & 運転者がすべての運転タスクを実施 & 運転者 \\
\hline 1 運転支援 & $\begin{array}{l}\text { システムが前後・左右のいずれかの車両制御に係る運転タスク } \\
\text { のサブタスクを実施 }\end{array}$ & 運転者 \\
\hline 2 部分運転自動化 & $\begin{array}{l}\text { システムが前後・左右の両方の車両制御に係る運転タスクのサ } \\
\text { ブタスクを実施 }\end{array}$ & 運転者 \\
\hline 3 条件付き運転自動化 & $\begin{array}{l}\text { システムが全ての運転タスクを実施（限定領域内）・作動継続 } \\
\text { が困難な場合の運転者は、システムの介入要求等に対して、適 } \\
\text { 切に応答することが期待される }\end{array}$ & $\begin{array}{l}\text { システム（作動継続が } \\
\text { 困難な場合は運転者） }\end{array}$ \\
\hline 4 高度運転自動化 & $\begin{array}{l}\text { システムが全ての運転タスクを実施（限定領域内）・作動継続 } \\
\text { が困難な場合、利用者が応答することは期待されない }\end{array}$ & システム \\
\hline 5 完全運転自動化 & $\begin{array}{l}\text { システムが全ての運転タスクを実施（限定領域内ではない）・ } \\
\text { 作動継続が困難な場合、利用者が応答することは期待されない }\end{array}$ & システム \\
\hline
\end{tabular}


るを得ない。ここでは、自動運転にかかるレべ ルの区分についてのみ掲げておく（表1参照）。 一言触れておくならば、SAE $\mathrm{S}^{\mathrm{ii}} \mathrm{J} 3016$ は、自動 運転技術の評価にあたって、自動運転レベルと ともに、「限定領域 (ODD)」の範囲が重要な 指標になると指摘している。すなわち、 $\mathrm{SAE}$ レベル 1 〜レベル4のいずれにおいても、その 運転自動化システムが機能すべく設計されて いる特有の条件である限定領域 (ODD) が広 いほど技術的な高度性が高く、言い換えれば、 SAEレベル4（完全自動運転の一部）であって も、狭い限定領域（ODD）のみで運転が自動 化されるシステムであれば、技術的な高度性は 相対的に低い。なお、SAE J3016は、わが国で もJASO化されている。

\section{法的議論の概観}

（1）自動運転にかかる法的議論の特徵を幾つ か述べておく。

第一に、既存の法体系と自動運転の関係であ る。今日の自動運転システムは、人工知能 $(\mathrm{AI})$ によるビッグデータ分析に依拠するものである が、従来の法制度が前提としていない種々の問 題を含んでいる（事故の場合の刑事責任を負う のは誰かなど)。

第二に、国際的ルールの形成と法ということ について一言触れておく。自動運転に関連する 国際的な法的枠組みとして、ジュネーブ道路 交通条約（1949、道路交通に関する条約［昭 和 39 年条約第 17 号]）とウィーン道路交通条約
PROFILE

藤原靜雄（ふじわら しずお）

口央大学法務研究科教授

專門 行政法、情報法

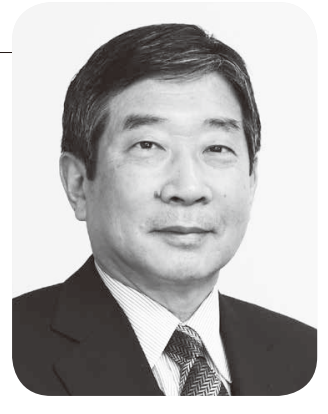

（1968）がある（前者のジュネーブ条約にはわ が国や米国などが加盟しており、後者のウィー ン条約にはドイツをはじめとしてEUの主要国 が加盟している)。このジュネーブ条約の存在 が、自動運転の実現化の議論における大きな難 問となっている。すなわち、ジュネーブ条約で は、「運転者」の存在が前提とされており、運 転者が車両の操作に全く関与しない状態（レベ ル4・5）は、本来、前提とされていない。自 動運転の実現にあたって運転者のコントロール 下にあることが必要条件となる。わが国の現行 道路交通法（以下、道交法）も、運転者に対し て、同条に規定する安全運転の義務を始めとす る様々な義務を課している。ジュネーブ条約を 前提としていると言い換えることもできる。条 約と自動運転との整合性についての議論にはわ が国も参加しているが、そもそも70年前の条 約を前提とした議論をすること自体に問題があ るとも言える（ウィーン条約については、2014 年にレベル 4 の自動運転を認める方向の修正が なされ、2016年 3 月発効している)。

第三に、法制は過渡期の法制にならざるを得 ないということである。固定的に決めてしまう と技術の進展や自由な議論を阻害するおそれが あるからである。過渡期の法制では、自動運転 車を特別のものとして規律するか、逆に言えば、 どこまで一般の交通主体として規律するかの問 題が生じる。 


\section{個別法をめぐる論点}

\section{（1）論点の分類と関係法律}

自動運転に係る関係者としては、自動車の製 造者・販売者・整備工場、基本ソフト及びハー ドの提供者、ネットの運営者、アプリケーショ ンの提供者、車の所有者・使用者・リース業者・ 貸与者・運送業者、保険事業者、広告業者等が ある。これらの者に係る法律関係が、自動運転 車の導入によって変わるかの検討作業が必要と なるわけである。以下では、どのような法律に ついて議論の余地があると認識されているか概 観する意味で、法律別の論点を一瞥しておきた い。

（2）法律別の論点整理においては、以下のよ うな整理が可能である（一応解決された問題 も今後の問題もある)。

(1)運転手／運行供用者／使用者／事業者の責 任（道路運送法、自動車損害賠償保障法 [運 行供用者についてどう考えるか、免責要件 は、例えばレベル 5 の車がハッキングされ て事故を起こしたときの責任はどうなるの か］、民法、刑法、自動車運転死傷行為処 罰法)、

(2)製造物・営造物責任（製造物責任法［自動 運転システムを構成するソフトウェア自体 は製造物でない点をどうするか、自動運転 車の欠陷 $=$ 当該製造物が通常有すべき安全 性の基準はどうなるか]、国家賠償法、道 路整備特別措置法)、
(3)事業者の責任とユーザー（消費者）の義務 （1）民法、刑法に加えて、景品表示法、 消費者契約法、道路運送車両法、貨物自動 車運送事業法、道路運送法、旅客自動車運 送事業運輸規則)、

(4)自動走行の事故調査及び保険会社側損害保 険契約に基づく填補責任（運輸安全委員会 設置法、道路交通法、保険法)、

(5)サイバーセキュリティに関する法律（著作 権法、不正アクセス禁止法、不正競争防止 法、個人情報保護法 [例えば、自動走行シ ステムが取得・提供することが予定されて いる情報には個人のライフログ（個人の生 活や行動の履歴）情報も多く含まれるが個 人情報の保護とどう調和させるか]）、 が掲げられている。

\section{（3）道路交通法}

道路交通に関する規制は、道交法と道路運送 車両法の二つの法律によってなされる。前者は 運転者が守るべきルールを、後者は自動車が満 たすべき基準を定める。この二つの法律の改正 法が2019年5月 28 日同時に成立している。レ ベル 3 以上の場合、レベル 2 以下では運転者が していた「認知・判断・操作」という作用をシ ステムが代替するようになるが、道交法はレべ ル 3 に対応すべく改正されたものである。改正 法は、レベル 3 以上の自動運転も許されるが、 同時に、「自動運行装置を使う行為者」を道交 法上の運転者に課せられた義務を負うとしたも のである。主たる改正点は、第一に、「自動運 
行装置」という定義（道路運送車両法 41 条第 1 項第 20 号の定義を引用 [簡略化すれば、レベ ル 3 以上の自動運転システムで、デー夕記録機 能を付けてるもの]）を設けた上で、「自動運行 装置を使って自動車を使う行為」を、道交法上 の「運転行為」に含むと位置づけた点、第二に、 「運行装置を使って自動車を使う運転者」がど のような義務を課されるかを明らかにした点、 第三に、「作動状態記録装置」の規定を整備し、 データ記録装置の搭載等を義務付けた点であ る。

なお、改正道交法では一定の要件を満たす限 りではあるが、携帯電話と画像注視が許される ようになる。

\section{（4）道路運送車両法}

主たる改正点は、第一に、自動運行装置の定 義を設けた上で、これを保安基準の対象となる 自動車の装置に追加した点（保安基準は国際協 調の観点から国連のWP29の議論も踏まえなが ら、今後、国土交通省令で定められる)、第二に、 自動運行装置等に組み达まれたプログラムの改 変等に係る許可制度を創設した点、第三に、自 動運転において重要となる電子的な検査のため の技術情報の管理をどこの機関が行うか（独立 行政法人自動車技術総合機構）を明らかにした 点、第四に、対象整備に自動運行装置の整備等 を追加し、メーカー等に対し点検整備に関する 情報提供義務を課した点である。

\section{おわりに}

この他にも、自動運転車が対向車との衝突を 避けるためにハンドルを切ると歩行者を轢いて しまう場合の問題（近時トロッコ問題とよばれ る、以前からカルネアデスの板、緊急避難の問 題として存在する問題である）や運転者の存在 を前提とする道交法の体系はレベル 4 以上では どう修正されるべきかといった問題もある。自 動運転について考えるべき法的課題は尽きな w。

注

i なお、2018 年には自動運転に係る制度整備大綱が内閣官房 のIT 総合戦略室から公にされている。

ii SAE International (Society of Automotive Engineers:科学者、 エンジニア等からなるフォーラム) 